\title{
TOWARD A SOCIAL PSYCHOLOGY OF FOOD USE ${ }^{1}$
}

\author{
Peggy A. Shifflett \\ Kenneth L. Nyberg \\ Texas A\&M University
}

Mid-American Review of Sociology, 1978, Vol. III, No. 2:35-54

This paper focuses on the social construction of food use patterns through the dialectical moments of externalization, objectivation, and internalization. The major emphasis is on the situational, intersubjective, and symbolic dimensions of food use which have most often been overlooked by normative programs and research. Also, the point is made that there is great diversity in food use patterns across groups and cultures and each is based upon different logic by which food use is organized. The "basic four" logic popular in middle-class America is not the food logic, but a food logic.

\section{INTRODUCTION}

Interest in food use patterns has been continuous throughout American history. During the colonial period, the major emphasis was the American Indians' food habits which were documented in travelers' accounts, memoirs, diaries, and correspondence. European and Oriental immigrants in the late nineteenth and twentieth centuries provided a vast resource of fresh material for study of food habits. Beginning in the mid-1890s the United States Department of Agriculture (USDA) and its Food Habits Research Program conducted numerous studies. At the same time, tremendous advances were occurring in the field of chemistry permitting increased knowledge of biochemistry and metabolic behavior (Freedman, 1971:170).

With the advances in bio-chemistry there was a new emphasis in the area of food habits research. Whereas earlier studies had been descriptive with some emphasis on understanding food habits as a cultural form brought about by person-environment interaction, the bio-chemists' concern was with nutrition, i.e., the 
physiological processes by which a human takes in and utilizes food substances. The socio-cultural dimension of food use was de-emphasized.

Most significant, however, was the development of a "standard" for food utilization-the "basic four", and Recommended Daily Allowances (RDAs)-which became the yardsticks to measure and evaluate nutritional statuses of populations in developing countries and subcultural groups in the United States.

When nutritional programs were found to be "substandard," educational programs based on the basic four and with an a posteriori therapeutic function were launched (DeGarine, 1971:51). These interventions into the habitual food use patterns of diverse peoples have been most often distinguished by "failure." Typically, these "failures" are of two types. In one, a given intervention is adopted by the people but fails to noticeably improve their nutritional status (Evers and McIntosh, 1977). In the other, the people simply do not accept the program as presented (Fathauer, 1960; Mead, 1953; Niehoff, 1969). Although the two types of "failure" are clearly related, our concern is primarily with the latter problem.

In analyzing this problem, this essay will (1) examine the consequences of using the "objective" basic four standard in defining the nutritional statuses and food use patterns of diverse people, and (2) initiate a social psychology of food use which examines the process by which food use patterns are socially constructed, how they take on an ontological status independent of their origin, and how they are perpetuated with extreme durability. In the final section of this paper, the relevance of these issues for nutrition programs and research will be considered.

\section{CONSEQUENCES OF “OBJECTIVE” EVALUATION OF NUTRITIONAL STATUS}

Since 1943, psychologists, anthropologists, and some nutritionists have continuously stressed the need to consider the socio-cultural dimension in the analysis of food use patterns (Mead, 1943; Committee on Food Habits, 1945; Fathauer, 1960;
Lamb, 1969; Niehoff, 1969; DeGarine, 1971; Lowenberg, 1974). These writers have also been critical of the so-called "objective" measures by which food use patterns have been defined as "good" or "bad."

If a group's food habits were defined as 'good', this meant that they habitually consumed food in conformity with the standards of eating to which the scientists conducting the study subscribed

(Committee on Food Habits, 1945:14).

DeGarine (1971:47) stressed the point that many studies of food habits in developing countries give transparent glimpses into valuable opinions which "... readily brand such habits as aberrations when measured against an idealized, scientific concept of food reduced to its nutritional, economic, or, in a stricter sense, organoleptic properties."3

Though not expressly concerned with food use, innumerable criticisms (Berger and Luckmann, 1966; Blumer, 1969; Natanson, 1963; Nyberg, 1977; Schutz and Luckmann, 1973) of the practice of such "normal science" have been presented (Kuhn, 1970). This paper will not echo these arguments, but rather proceeds from them in an effort to delineate an epistemology of food use patterns.

\section{THE SOCIAL CONSTRUCTION OF FOOD USE PATTERNS}

Succinctly, reality may be defined as "ways of knowing, things to be known" (Nyberg, 1976). As such, food use has both an epistemological and an ontological status. Very few studies have concentrated on the social construction of food use patterns; therefore, it is deemed necessary to stress that all food use patterns are socially constructed whether based on "scientific" reasoning or derived from the "magic" of remote tribes. The social construction of food use patterns occurs through the dialectic of externalization, objectivation, and internalization (Berger and Luckmann, 1966:61). 


\section{Externalization}

Regarding food use, externalization is the process by which humans, interacting with other humans and their physical environment, define various objects ${ }^{4}$ as food or nonfood. In this process, possible food objects provided by a specific physical and social environment are defined as edible or nonedible, edible by animals but not by human beings, edible by human beings but not my kind of human beings, edible by human beings like me but not by me, edible by me and so on (Lowenberg, 1970). No human group has defined as food every plant and animal in its environment. The over-used example of the sacred cow in India comes to mind and could be compared to Americans' aversion to horse and dog meat, both of which are as good a source of protein as beef and pork (Pyke, 1968).

Once an item has been defined as food, it takes on many additional meanings. Thus, carrots are not only food, but as a food they are nutritious, tasty, inexpensive, easy to prepare, "good for the eyes" and so on. Fish is not simply food but also an aphrodesiac, tasty, low status, and slimy as well.

What a person experiences when perceiving a carrot or fish is apperceptively transferred to any other object experienced as merely being carrot-like or fish-like. As more objects are experienced, the associated meanings will be confirmed, denied, extended, or subtyped so that fish-like objects become perch, flounder, oysters, or shrimp each with its own form of typicality (Natanson, 1962).

The meanings of food arise out of situations in which humans interact with other humans. For example, it has been noted (Bennett, 1944) that fish was once considered a low status food in the Ohio riverbottom area of the United States. This meaning of fish was derived from the changing definitions of fishing. At one time all riverbottom people caught their own fish. Gradually fishing was defined as "nasty" and became a specialty of lower-status riverbank squatters who began to catch and sell fish to make their living. Ultimately, the riverbank squatter fishermen were stereotypically defined:
Fishermen work just as hard as any farmer, but they ain't as good... Fishermen was always called thieves in them days.... There used to be a saying a fisherman had a hook fer anythin' he could catch (Bennett, 1944:564).

The definition of fishing as indiscriminant, and its association with riverbank squatters, determined, to a great extent, who ate fish and to whom it was served. More importantly, fish as food acquired a new and additional meaning-"low status" food-which became a part of the "world taken for granted" (Natanson, 1962) of the Ohio riverbottom people.

Therefore, through human interaction in which situations are defined and redefined, foods acquires a vast number of meanings. A specific meaning of a food is determined by the purpose at hand, thus:

If $I$, with respect to an element of $S$ [meaning of food] of the world taken for granted, assert: $S$ is $\mathrm{P}$ [fish is low status food], I do so because for my purpose at hand at this particular moment I am interested only in the p-being of $S$ [low status of fish] and am disregarding as not relevant to such purpose the fact that $S$ is also $q$ and $\mathbf{r . . . [ f i s h}$ is also nutritious and tasty]... (Natanson, 1962:76).

Clearly, social status is nothing which inheres in fish per se, yet it is precisely this organizing dimension which defines it. The "thing to be known" is necessarily correlated to the "way of knowing."

It is a remarkable social paradox that while humans define some items believed to be excellent sources of nutrients as nonfood, items with questionable nutritive value are defined as food. For example, lettuce and celery contain very few nutrients; yet, lettuce salad is commonly assumed to be a nutritious food. Milk has been defined as a "perfect food," yet milk alone cannot sustain health beyond the first few months of life. College athletes frequently consume prime steaks as their major meat source 
because they are defined as better for muscle building. A lowly pot roast or low-grade hamburger could supply equivalent nutritive value (Yetley, 1977).

Some American people are concerned that chemical additives which are purposefully added to foods by processors may be carcinogenic or toxic if consumed in large quantities while being unaware that many foods naturally contain chemical toxins or carcinogenic agents. For example, potatoes contain a toxic agent solanin which could be harmful if present in slightly greater quantities. Cabbage, turnips, and onions, all have specific toxic compounds. Also, strawberries contain coumarin, a pleasant-tasting aromatic organic compound, which if isolated and consumed, interferes with the clotting of blood (Pyke, 1968). Yet, some people have come to define "natural" food as good or pure and processed foods, with additives, as bad or dangerous (Yetley, 1977).

It is in this manner that we speak of the "externalization" of food use patterns: the paradox that humans are capable of producing a world that they then experience as something other than their own product.

\section{Objectivation}

Food use patterns are habitualized because they are reciprocally typical. Eventually, the habitualization and typification of food meanings become institutionalized; and with the acquisition of institutionalization, food meanings and their uses become objective... They now possess an ontological status of their own which confronts the individual as an external and coercive fact (Berger and Luckmann, 1966:57-58). What is most important, however-and often neglected by food habits studies-is that these "objective" meanings are, in fact, "subjective," reflecting various definitions of the situation at hand.

In general, two categories of situational definitions (Stebbins, 1972) are particularly important in understanding food use patterns: "cultural" definitions of the situation and "habitual-personal" definitions of the situation. Cultural definitions would include collective representations: the standard meanings of food and their situational meanings which are embedded in the community culture as a whole and are passed on through primary and secondary socialization. Habitual-personal definitions are structured cultural definitions but are unique in that they are used by categories of people in specific ways and in specific kinds of periodic situations that for one reason or another are not explicitly communicated. An example would be the daily preparation of foods to meet nourishment needs of a family. The person responsible for food preparation prepares food combinations according to texture, color, individual preferences and so on. The husband's steak is rare, the grandfather with a chewing problem has ground chuck, the child is given a small portion, the diabetic is not served pie or rich desserts in excess of the daily carbohydrate calculation. This meal is prepared and served without necessarily communicating its various functions which are taken to be mundane rules requiring the common-sense actors'-typically the woman's-indexical ${ }^{5}$ negotiation. Hence, there are "methods" for food preparation and presentation, and these methods are employed via implicit "logics-in-use." Moreover, it is precisely these "logics-in-use" which serve to operationalize situated definitions of food use.

Where nutrition education often fails is in recognizing that differing cultures not only prefer different foods but that the logic which organizes food also differs. The "basic four" logic popular in middle-class America is not the food logic, but rather $a$ food logic. Other cultures have objectified different "ways of knowing" food. For example, traditional Chinese view food as important in preventing and treating disease, and it is balanced according to its Yin and Yang ${ }^{6}$ components. In Chinese philosophy, "chi" (literally "air," "breath," or "wind") is an energy present in all living organisms. When metabolized, food is transformed into "chi" and becomes either a Yin (cold) or Yang (hot) force. Health is believed to be maintained by balancing "hot" and "cold" foods. Illnesses caused by Yin excesses are treated by "hot" foods; those caused by Yang excesses, by "cold" foods (Chang, 1974). 
A similar belief system is found among most Spanish-speaking people (Madsen, 1955; Rubel, 1960; Mazess, 1968; Harwood, 1971; Galli, 1975). It is also encountered in the Mediterranean, in Africa (DeGarine, 1972), and in Malaya (Wilson, 1971). In India the hot-cold belief system is termed "ayurvedic theory" and is based on the belief that there are five states of matter-earth (Prithvi); water (Ap); fire (Thejas); air (Vayu); and sky (Akash). Within the human body these states combine to become the Tridhatus-the elementary and fundamental units or principles on which depend the building and sustenance of the body. When the Tridhatus are in equilibrium, the body is in a state of health; when there is disequilibrium, then ill health or disease follow. Food is an important element in maintaining equilibrium. The wrong types and combinations of "hot" and "cold" foods can cause disequilibrium (Ashkenaz et al., ca. 1972:69-70).

All these systems classify foods as "hot" or "cold" regardless of their physical properties. The beliefs are related to attributes such as sex and age, or to situations such as disease, pregnancy, and lactation. The circumstances are classified in a systematic way, authorizing the therapeutic nutritional use of corresponding foods (DeGarine, 1972:149).

Similarly, Americans have common-sense "logics-in-use" which organize their food use "stock-of-knowledge" (Schutz and Luckmann, 1973) such as the respective "starving" and "feeding" of colds and fevers; the "balanced" diet; peppers which "put hair on your chest," and so on. Though no less mystical, these belief systems are sometimes more formalized. Instead of eating a balanced diet of hot and cold foods, modern Americans try to balance by the basic four which provides nutrients. The recommended amounts of nutrients vary by attributes and situations. For instance, it is emphasized that women should consume more foods containing iron which restores the loss due to the menstrual flow. If certain illnesses occur, a person is given larger portions of the nutrient which is believed will cure the condition. For example, scurvy is a disease caused by a lack of vitamin C. Consequently, large doses of vitamin $\mathrm{C}$ are prescribed for this illness. Also, it is believed that certain nutrients consumed in excess such as vitamins A and D may cause illness.?
Therefore, through the process of externalization and objectivation (Berger and Luckmann, 1966), food use patterns are defined and redefined, so that they make up a part of the social stock of knowledge. Included are typificatory food use patterns or "recipe knowledge" required for meeting the biological need for nourishment. These typical patterns are those experienced by the individual as well as by others before him (Natanson, 1962).

\section{Internalization}

The social stock of knowledge is perpetuated in society by the internalization process, the third moment in the dialectic of the social construction of reality (Berger and Luckmann, 1966). It is in the process of internalization that an individual's biological need for nourishment is transformed into culturally patterned appetite.

The newborn infant is hungry, has an efficient sucking apparatus, and can root for the nipple. He also has the ability to digest and metabolize milk for his needs. Think what he must learn about foods and eating before he becomes a self-sufficient human being. He must learn thousands of new flavors and texture combinations in foods, as well as differences in temperatures in foods, when they are ready to be eaten. In addition, to eat acceptably in his group, he must learn many things, such as when he can expect to be fed, what foods are considered proper at certain times of day, and even where he gets different kinds of foods. He will learn, if he is a boy, that certain foods are considered masculine and some which he may even like are too feminine for him to favor (Lowenberg, 1974:267).

Primary socialization occurs under circumstances that are highly charged emotionally. In a given family a "mother ... communicates many things [to her child] by the way she presents food.... The infant probably first learns about love at feeding time" (Lowenberg, 1974:268). Moreover, primary socialization is augmented, dialectically, by secondary socialization-"the internalization of institutional or institution-based subworlds" (Berger and Luckmann, 1966:138). 
Conflict between primary and secondary socialization occurs in a variety of situations. For example, a pregnant woman may be given a specific diet plan by her doctor to insure a healthy child. She may accept this diet because in school she learned about the importance of proper food use during pregnancy. However, when she examines it closely, she notes that the list of suggested foods includes fresh strawberries. From her stock of knowledge acquired in primary socialization, she recalls a warning passed to her by her mother that if a pregnant woman eats strawberries, the baby will have "strawberry" birthmarks (Shifflett, 1976). Out of a balancing of knowledge acquired in primary versus secondary socialization, the woman eats strawberries, does not eat strawberries, or modifies her eating of strawberries. Depending upon the strength of this belief acquired in primary socialization, the presence of one taboo food-strawberries-on a diet plan, may negate validity of the total recommendation.

Thus, the dialectic may be seen to reflect the degree of responsiveness to the demands of one social world and the adoption of the perspective of another (Shibutani, 1972:171). The "tension" (Zaner, 1970) of multiple realities is not a sociological abstraction, but a real trauma to everyday actors, thus in the hypothetical illustration the woman probably will not eat strawberries:

It takes severe biographical shocks to disintegrate the massive reality internalized in early childhood [primary socialization]; much less to destroy the realities internalized later [secondary socializatiơn] '(Berger and Luckmänn, 1966:142).

\section{TOWARD A SOCIAL PSYCHOLOGY OF FOOD USE}

Thus far we have considered the mundanely reified, problematic status of food use. In this regard, a human is aware of being hungry rather than merely being hungry. In other words, the human acts toward his or her physiological hunger by interpreting it and transforming it into culturally-patterned appetite, and then organizes his or her action to satiate hunger on the basis of this interpretation.
The process of self-interaction in being aware of hunger puts humans over against their world instead of merely in it; requires them to meet and handle their need for nourishment through a defining process instead of merely responding to it; and forces them to construct their action instead of merely releasing it (Blumer, 1969:63). The result is the social construction of food use patterns.

Additionally, we have argued these patterns to be multiple. The epistemological (i.e., way of knowing) and ontological (i.e., thing to be known) status of food is situated, and differs across groups and cultures. People of Spanish origin accomplish food use differently than do people of Anglo or Chinese origin, which in turn differ. In short, we have cautioned against an ethnocentric conceptualization of food use and against the tendency to treat food use as a kinematic, as opposed to a dynamic, phenomena. Food use is a subjective process not an objective state.

Here we do not merely echo common and redundant sentiments regarding the "social nature" of food and its uses. What concerns us-and what is prototypical for the development of a social psychology of food use-is the explicit description of the epistemological structures which organize, i.e., make sense of, food use and thus make food use patterns possible in the first place. As such, the first priority is one of syntax, not substance. It is far less important-and less useful-that one knows that particular food " $x$ " represents a pecan rather than an apple, than that one can make explicit the logical equation in which " $x$ " is related to $p, b$, and $y$, e.g., $(x+p)=(b+y)$, or $(x+p+b)=y$, or $\left(x+\frac{p}{b}\right) \neq y$, etcetera. Making explicit these implicit structures (Zaner, 1973) yields the format within which particular phenomena take on meaning, and, in effect, become what they are-a mundane hermeneutics.

What we are proposing is a considerably different focus of attention. Necessarily, food substances are categorized. However, their categoricality does not specify the manner in which one category is related to another, and it is in the specification of the "relationship" that a social psychology of food use is constructed. 
In this sense, then, dilemmas in "acculturation" (Gupta, 1975) are not primarily posed by dichotomous functions of specific "proscriptivity" and "prescriptivity," but rather because (1) the biographical culture's relational syntax is different from the adoptive one, or (2) the particular food stuff is not perceived as a constituent of a meaningful food category, or (3) both of these. As such, the meaningful program of determining specific elements (i.e., foods) of given sets (i.e., food meaning categories) as they are, in fact, situated in the biographical culture must not be accomplished without also determining the manner in which food meaning categories relate to one another, for it is out of this context that a "logic-in-use" emanates and becomes operational.

That this "logic-in-use" is social is obvious. Less obvious, however, is the process by which the logic becomes subjectively and intersubjectively grounded. This subjective process is extraordinarily complex. In general, before each meal the person in charge of preparation deliberates by placing himself or herself in a future time when the act (meal) has been completed. During this time of deliberation or projecting, the person becomes aware of "in-order-to-motives" (Natanson, 1962) which are ends to be achieved or goals sought. Examples may be to "feed the family a nutritious meal," "impress the guests who are coming to dinner," "express ethnicity," and so on. It is in the process of projecting the meal that the self, others, meanings of foods, and definitions of the situation are all incorporated into food use patterns, i.e., certain foods come to mind to be rejected or selected to fit the situation. Out of this dialectic, a meal emerges.

Implicit in this process are both "rules" and "methods," and it is precisely these which constitute the fundamental parameters for a social psychology of food use. Simply stated, "rules" are structures of relationship and value which organize social reality, while "methods" are those cognitive and behavioral practices which negotiate rules and give evidence of "logics-in-use". In this regard, food use patterns are seen to be situated, organized and negotiated by common-sense actors in their taken-for-granted world (Garfinkel, 1967), and as such, these "organizing" and "negotiating" dimensions become the prime data for a social psychological study of food use.
Research which ignores these dimensions is not strict and may be ultimately meaningless. Because these dimensions are not easily objectified and quantified, they have been silently ignored while data on the family budget and food consumption are collected (DeGarine, 1971:57).

The researcher who overlooks these situated "organizing" and "negotiating" structures is not studying the nutrition and food use of, say, the Ethiopian-but rather is studying his or her own food use pattern vis-a-vis the Ethiopian: the difference between a "first-order" and "second-order" construct (Natanson, 1962). As Logan and Hunt (1978:xv) note, "nutritional programs are frequently instituted without an understanding of the cultural context and are often marked by failure or harmful prescriptions."

An example of this problem is the continued shipment of American nutritionists' conception of nature's most perfect food-milk-to cultures where it is viewed with disgust and is given a status equal to blood or urine. Most important, however, is that some people cannot metabolize milk because they lack an enzyme (lactase) needed to break down milk sugar (lactose). Africans, Asians, Greeks, and American Indians frequently develop diarrhea and stomach cramps after drinking milk (Logan and Hunt, 1978:xv). Inspite of these barriers, Chile recently received 107 million pounds of powdered milk after a similar program in Guatemalan and Columbian villages resulted in the villagers' using the milk to whitewash their huts (McCracken, 1971).

The function of a social psychology of food use is the description and analysis of those "organizing" and "negotiating" structures which indexically define nutrition. Most nutritional studies and programs overlook this crucial dimension. Hence, a high degree of failure results. Though often the reason for such failure is mistaken for a lack of "motivation" on the clients' part (Lamb, 1970), the recognition of failure is clear (Wilson, 1971; Fathauer, 1960; Mead, 1953; Logan and Hunt, 1978; Pelto and Jerome, 1978); and the basic reason for such failure is that

new knowledge will be accepted only in so far as it can be made to fit into the general pattern of custom and belief of people (Jelliffe, 1967:279). 
In other words, we must honor more strictly Husserl's (1965) admonition "to know the what of the very concepts we employ."

In this regard, the concept is "food use" and we often do not know what we are talking about. The first order of agenda, then, is a thoroughly critical description of food use constructs as they are indexically organized and negotiated. Knowledge of not only what people eat, but why they eat what they eat, is essential. Whether we are concerned with the "basic four" or "ayurvedic theory"-the task remains identical: to determine the "logics-in-use" which govern what people eat. If we understand these schematas, meaningful and minimally traumatizing substitutions can be made.

Examining food use as situationally determined social action implies, minimally, a verstehende sociology. If social scientists are to comprehend the food use patterns of individuals and groups, they must learn to "take the role of the other" (Mead, 1934). They must gain an understanding of the food user's point of view of social reality, his or her symbols, attitudes, food meanings and values, i.e., Weltanschaungen and Lebenswelt (Schutz and Luckmann, 1973). Research must recognize the "evolutionary creativeness of social acts"-that humans are continually remaking their social and physical environment. The social order is always in a state of becoming (Blumer, 1962:20-38), and a methodology that imposes "fixed rigid categories upon a social world in the throes of evolution" (Sjoberg and Nett, 1968:6) is inadequate.

As with the carpenter, failure to determine the "logics-in-use" of food cannot be blamed on our tools. Strategies abound (Cicourel, 1964; Garfinkel, 1967; Blumer, 1969; Zimmerman and Wieder, 1977) and though significant differences exist regarding the radical grounds of these programs (Nyberg, 1977), each carries with it essential criteria for strict description and analysis.

\section{SUMMARY}

Put simply, food is more than what one eats. What one believes about food is also relevant. As Wilson (1971:98) noted:
Food beliefs are ... of critical importance to the food and nutrient status of the people studied. Equally important is the fact that these beliefs themselves are important to the people holding them. They will not be easily given up since they are a part of everyone from their earliest days, intimately and reciprocally binding them to their environment as they perceive it.

In these pages we have tried to show that these "beliefs" are in fact reflective of a larger social reality, a reality which is situated, organized and negotiated by members who in their "natural attitude" (Schutz and Luckmann, 1973) constitute it an objective fact. Through the dialectical moments of "externalization," "objectivation," and "internalization" (Berger and Luckmann, 1966), we have indicated the processural stages which facilitate this constitution and the various definitions of situation, self and others which are, in turn relevant. In short, a social psychology of food use has been presented.

\section{NOTES}

1. Though the authors assume full responsibility for the manuscript, expressed appreciation is extended to James H. Copp, William Alex McIntosh, C. Eddie Palmer, D. Lawrence Wieder, Mervin Yetley, and Dorothy Noel for their constructive commentary and criticism. A special indebtedness is acknowledged to Elizabeth Yetley, Susan Evers, and Dorothy M. Rowe for their corrective advice in particular areas of nutrition.

2. "Basic four" refers to four food groups-milk, meat, vegetables-fruits, and breads-cereals. A diet with a minimum number of daily servings from these food groups will provide nutrients-proteins, minerals, vitamins, fats, carbohydrates-which are essential to good health.

3. When food use patterns of diverse people are labeled "bad" through the extrapolation of Western industrial images of scientifically approved "objective" nutritional standards, the concern is with what caused them and how they can be changed. In essence, "total social facts" (Mauss, 1950) i.e., food use patterns, which are susceptible to the influence of a society's full range of activities-technical, economic, social, personal, 
juridicial, and religious-are separated from the social context and evaluated in terms of food use patterns as socially constructed in "scientific" Western industrial society (DeGarine, 1971:46-47).

4. According to Mead, humans live in an environment of objects around which their activities are formed. The nature of an object is constituted by the meaning it has for the person or persons for whom it is an object. This meaning is not intrinsic to the object but arises from how the person is initially prepared to act toward it. Objects are social products formed and transformed by the defining process that occurs in social interaction. People act toward objects on the basis of meaning of the objects for them. Because an object is something that is designated, a person can organize action toward it instead of responding immediately to it (Mead, 1934:77-80).

5. "Indexicality" refers to the inherently situated constitution of social action. Focus, here, implies the opposite of "objective," which is constitutionally decontextualized (Garfinkel, 1967:4), and thus a radical departure from "practical sociological reasoning" (Garfinkel, 1967:4ff).

6. The traditional Chinese view of the universe includes the belief that elemental forces control the universe and affect all aspects of human endeavor. Two opposing components, the Yin and the Yang, regulate the universe. The Yin component includes female, darkness, cold, and emptiness. The Yang component includes male, light, warmth, and fullness. All things or beings in the universe are believed to consist of a Yin and a Yang. To maintain peace and harmony in society and health in the mind and body, these forces must be in perfect balance. An imbalance of Yin and Yang is believed to cause catastrophe and illness.

7. There are contradictions in this system as they are in the Chinese and other system. For instance, the modern western specialists in America recommend $45 \mathrm{mg}$. of vitamin $\mathrm{C}$ per day for a man; while the modern western specialists in Britain recommend $30 \mathrm{mg}$. "Both cling with equal zeal to their respective beliefs" (Pyke, 1968:93-94).

\section{REFERENCES}

Ashkenaz, E., et al.

1972 Cultural Anthropology and Nutrition: The Tamil Nadu Nutrition Study, Vol. II, Section B. Report to the U.S. Agency for International Development. Haverford, Pa.: Sidney M. Cantor Associates, Inc.
Food Use

Bennett, J.W.

1944 "Food and Social Status in a Rural Society." American Sociological Review 10:346-354.

Berger, P.L. and Luckmann, T.

1966 The Social Construction of Reality. Garden City, N.Y.: Doubleday and Company, Inc.

Blumer, $\mathrm{H}$.

1962 "Society as Symbolic Interaction." In A. Rose ed., Human Behavior and Social Processes. Boston: Houghton Mifflin.

1969 Symbolic Interactionism: Perspective and Method. Englewood Cliff, N.J.: Prentice-Hall, Inc.

Chang, B.

1974 "Some Dietary Beliefs in Chinese Folk Culture." Journal of Cicourel, A. V. the American Dietetic Association 65:436-439.

1964 Method and Measurement in Sociology. New York: Free Press.

Committee on Food Habits

1945 Manual for the Study of Food Habits. National Research Council Bulletin No. 111. Washington, D.C.: National Academy of Science.

DeGarine, I.

1971 "Food is not just Something to Eat." Ceres FAO Review 4:47-51.

1972 "The Socio-Cultural Aspects of Nutrition." Ecology of Food and Nutrition 1:143-163.

Evers, S. and McIntosh, W.A.

1977 "Social Indicators of Human Nutrition: Measures of Fathauer, G. Nutritional Status." Social Indicators Research 4:185-205.

1960 "Food Habits-An Anthropologist's View." Joumal of the

Fewster, W.J. American Dietetic Association 37:335-338.

1973 "Measuring the Connotative Meanings of Foods." Home Economics Research Journal 2:44-53.

Freedman, R.L.

1971 "The State of Food Habits Research in the United States of America." In Bibliographic Bulletin of American Anthropology XXXIII-XXXIV. Mexico: Institute of Pan

Galli, N. American Geography and History, Commission of History.

1975 "The Influence of Cultural Heritage on the Health Status of Puerto Ricans." Journal of School Health XLV:10-16. 
Garfinkel, $\mathrm{H}$.

1967 Studies in Ethnomethodology. Englewood Cliffs, N.J.: Prentice-Hall, Inc.

Gupta, S.P.

1975 "Changes in the Food Habits of Asian Indians in the United States: A Case Study." Sociology and Social Research $60: 87-99$.

Harwood, A.

1971 "The Hot-Cold Theory of Disease: Implications for Treatment of Puerto Rican Patients." Journal of the American Medical Association 216:1153-1158.

Husserl, E.

1965 Phenomenology and the Crisis of Philosophy. New York: Harper Torchbooks.

Jelliffe, D.B.

1967 "Parallel Food Classifications in Developing and Industrialized Countries." American Journal of Clinical Nutrition 20:279-281.

Kuhn, T.

1970 The Structure of Scientific Revolution. Chicago: University of Chicago Press.

Lamb, M.W.

1969 "Food Acceptance: A Challenge to Nutrition Education-A Review." Journal of Nutrition Education (Fall):20-21.

Logan, M.H. and Hunt, E.E., Jr.

1978 Health and the Human Condition: Perspectives on Medical Anthropology. North Scituate, Mass.: Duxbury Press.

\section{Lowenberg, M.E.}

1970 "Socio-Cultural Basis of Food Habits." Food Technology 24:27-31.

1974 "The Development of Food Patterns." Journal of the American Dietetic Association 65:263-268.

Madsen, W.

1955 "Hot and Cold in the Universe of San Francisco Tecospa, Valley of Mexico." Journal of American Folklore 68:123-138.

Malville, $\mathrm{K}$.

1975 A Feather for Daedalus: Explorations in Science and Myth. Menlo Park, Calif.: Cummings Publishing Co.

Mauss, $\mathrm{M}$.

1950 Sociologie et Anthropologie. Paris.
Mazess, R.B.

1968 "Hot-Cold Beliefs Among Andean Peasants." Journal of the American Dietetic Association 53:109-113.

McCracken, R.D.

1971 "Lactase Deficiency: An Example of Dietary Evolution." Current Anthropology 12:479-517.

Mead, G.H.

1934 Mind, Self and Society. Chicago: University of Chicago

Mead, $M$.

1953 World Federation for Mental Health: Cultural Patterns and Technical Change. Tensions and Technology Series No. 8. Paris, France: UNESCO.

1964 Food Habits Research: Problems of the 1960's. Washington, D.C.: National Research Council Publication 1225.

Natanson, $M$.

1962 Schutz, Alfred: Collected Papers I: The Problem of Social Reality. The Hague, Netherlands: Martinus Nujhoff.

1963 Philosophy of the Social Sciences. New York: Random House.

Niehoff, A.

1969 "Changing Food Habits." Journal of Nutrition Education (Summer):10-11.

Nyberg, K.L.

1976 "Sociological Social Psychology: Crisis and the Parameters of Radical Reconstitution." Paper presented at the Annual Meeting of the Western Sociological Association, Tempe, Arizona.

1977 "Some Comments on Phenomenological and Sociological Theory and Practice." Review of Social Theory 4:5-8.

Pelto, G. and Jerome, N.W.

1978 "Intracultural Diversity and Nutritional Anthropology." In M.H. Logan and E.E. Hunt, Jr. eds., Health and the Human Condition: Perspectives on Medical Anthropology. North Scituate, Mass.: Duxbury Press.

Pyke, $M$.

1968 Food and Society. London: Cox and Wyman, Ltd.

Rubel, A.J.

1960 "Concepts of Disease in Mexican-American Culture." American Anthropologist 62:794-814.

Schutz, A. and Luckmann, T.

1973 Structures of the Life World. Evanston, Ill.: Northwestern University Press. 
Mid-American Review of Sociology

Shibutani, T.

1972 "Reference Groups as Perspectives." In J.G. Manis and B.N. Meltzer eds., Symbolic Interaction. Boston: Allyn and Bacon, Inc.

Shifflet, P.A.

1976 "Folklore and Food Habits." Journal of the American Dietetic Association 68:347-350.

Sjoberg, $\mathrm{G}$. and Nett, $\mathrm{R}$.

1968 A Methodology for Social Research. New York: Harper and Row, Publishers.

Stebbins, R.A.

1972 "Studying the Definition of the Situation: Theory and Field Research Strategies." In J.G. Manis and B.N.Meltzer eds., Symbolic Interaction. Boston: Allyn and Bacon, Inc.

Wilson, C.S.

1971 "Food Beliefs Affect Nutritional Status of Malay Fisherfolk." Journal of Nutrition Education (Winter):96-98.

Yetley, E.

1977 Personal Correspondence.

Zaner, R.

1970 The Way of Phenomology: Criticism as a Philosophical Discipline. New York: Pegasus.

1973 "Solitude and Sociality: The Critical Foundations of the Social Sciences." In G. Psathas ed., Phenomenological Sociology: Issues and Applications. New York: Wiley.

Zimmerman, D. and Wieder, D.L.

1977 "The Diary: Diary-Interview Method." Urban Life 5:479-498.

\section{LABELING AND OPPRESSION: WITCHCRAFT IN MEDIEVAL EUROPE}

\author{
Mary Ann Campbell \\ Washington University
}

Mid-American Review of Sociology, Vol. III, No. 2:55-82

The attempt here is to understand the social conditions and processes through which witches were labeled, hunted and persecuted in Europe during the Middle Ages. An historical analysis, utilizing anthropological accounts, Church doctrines and handbooks from the Inquisition, as well as testimonies, notes and sentences from witch trials, identifies the Church as labeler and the witch as rule-breaker. Throughout Church proclamations and convicting testimonies, there run three strands of indictment against witches: they did not worship the Christian God; they used magical powers to help or harm people; and they threatened or harmed men sexually. It is shown how these witches, many of whom were peasant healers, represented threats to the entrenchment of the Church, the legitimation of medicine as an honorable profession, and the perpetuation of patriarchal authority. It is submitted that the witch-image was created by the Christian Church, with support from secular rulers and "professional" medical practitioners, to eradicate persistent pagan religions and lay healing practices, including midwifery. This image of woman as evil incarnate, and the accompanying sex oppression, has persisted through the centuries. Modern-day implications of the witch-image are discussed in light of the current women's culture movement.

The topic of concern in this paper, witchcraft in medieval Europe, has not to my knowledge benefited from close examination of an explicitly sociological nature. There is as yet no competing body of explanations for the phenomenon, or much discussion of it in sociological literature. The subject has been explored by historians and cultural anthropologists, the latter mainly in terms of the social cohesion function of ritual and belief in magic. Medical treatises mention it as "primitive" or "unscientific" healing, while the psychiatric approach has been to 